\title{
Wild Triatoma infestans, a potential threat that needs to be monitored
}

\author{
François Noireau \\ UR 016, Institut de Recherche pour le Développement, Montpellier, France, \\ IIBISMED, Facultad de Medicina, Universidad Mayor de San Simón, Cochabamba, Bolivia
}

\begin{abstract}
The current persistence of Triatoma infestans, and therefore of Chagas disease transmission, in the Andean valleys of Bolivia and the Gran Chaco (precisely where wild populations of the vector are widespread), indicates a possible relationship between these two occurrences. This paper provides an overview of the current knowledge regarding wild $\mathrm{T}$. infestans in Bolivia. The different morphs of the wild vector, their known distributions and some traits of their biology and ecology are presented. Particularly interesting is the considerable behavioural and chromatic plasticity that is displayed by wild $\mathrm{T}$. infestans. According to the biogeographic region, different morphs of the vector occur in rupicolous habitats (common form and Mataral morph in Andean wild T. infestans) or arboreal ones ("dark morph" populations from the Chaco). The high genetic variability found at the microgeographical scale in Andean wild $\mathrm{T}$. infestans favours the hypothesis that the Andes were the centre of origin and dispersal of $\mathrm{T}$. infestans throughout South America. The relevant question regarding the origin of domestic populations is also addressed. Finally, current considerations of the epidemiological significance of wild $\mathrm{T}$. infestans are discussed in the context of recent discoveries. Even if several observations support the epidemiological risk represented by wild $\mathrm{T}$. infestans, the climatic and environmental conditions of their distribution areas would not favour the continued flow of triatomines between sylvatic refuges and domestic environments.
\end{abstract}

Key words: Chagas disease - Triatoma infestans - sylvatic foci - Bolivia

Triatoma infestans (Reduviidae, Triatominae) was, and still remains, the most important and widespread vector of Chagas disease in South America and it is the target of control programs as part of the Southern Cone Initiative (Dias 2007). The maximum estimated distribution range of T. infestans, reached during the 1970s, covered the 12 most populated states of Brazil and vast areas of Bolivia, Southern Peru, Chile, Northern Argentina, Paraguay and Uruguay; current estimates show that the distribution of the vector has been reduced by over $80 \%$, but $T$. infestans foci persist in the highland valleys of Bolivia and in the Gran Chaco Region (Schofield et al. 2006). When the Southern Cone Initiative was launched, in 1991, its expected success relied on some peculiar traits of the vector, in particular its lack of insecticide resistance and its almost exclusively domestic nature, as wild populations had only been detected in the highland valley of Cochabamba, in Central Bolivia (Schmunis et al. 1996). This latter characteristic, which in principle precluded the recolonisation of treated areas by insects from sylvatic environments, was a pivotal argument for undertaking large-scale control campaigns. Recent reports provide evidence that wild populations of $T$. infes-

Financial support: IRD, CNPq, UNDP/World Bank/WHO - Special Programme for Research and Training in Tropical Diseases (A50678, A70596), ANR, IDRC

Corresponding author: francois.noireau@ird.fr

Received 27 March 2009

Accepted 4 June 2009 tans are much more widespread than previously thought, drawing attention to the need for further research on this important and neglected issue, particularly on the role that such wild populations may play in the process of recolonisation of insecticide-treated villages (Noireau et al. 2005). This paper provides an overview of the current knowledge on T. infestans wild foci.

\section{Brief history of the discovery of wild T. infestans in Bolivia and other Southern Cone countries}

Wild T. infestans populations were first reported more than 60 years ago on a rocky hill situated in the immediate outskirts of Cochabamba, an important Bolivian Andean city 2,600 m above sea level (asl) (Torrico 1946). During the $1980 \mathrm{~s}$, wild $T$. infestans were also documented at other sites in the Cochabamba and nearby valleys (Dujardin et al. 1987, Bermudez et al. 1993). From the late 1990s to the present, new foci have been detected in the Andean departments of Cochabamba, La Paz, Chuquisaca and Potosi (Noireau et al. 2005, Cortez et al. 2007). Wild T. infestans populations have also been found outside the Andes, in the lowlands of the Boreal Chaco (Noireau et al. 1997). The existence of wild populations in the Chaco biogeographical region was later suspected in Paraguay (Yeo et al. 2005) and confirmed in the Chaco province of Argentina (Ceballos et al. 2009). Finally, sylvatic colonies of T. infestans were recently reported in the Metropolitan Region of Chile (Bacigalupo et al. 2006). These studies shed new light on earlier ones reporting the occasional finding of T. infestans specimens in a great variety of sylvatic ecotopes in Argentina, Paraguay and Brazil (Mazza 1943, Velasquez \& González 1959, Barretto et al. 1963, Bejarano 1967, Cichero et al. 1984). However, in spite of 
such records, the idea that $T$. infestans did not maintain sylvatic foci became mainstream simply because most specimens had been found in ecotopes relatively close to human dwellings (Usinger el al. 1966).

\section{Known distribution range of wild $T$. infestans}

Recent field surveys have revealed that wild $T$. infestans populations are much more widespread throughout Bolivia (and also in neighbouring countries) than previously thought. This discovery was largely the result of a simple trapping system that provided an effective way to detect the presence of T. infestans in hard-toreach terrestrial and arboreal sylvatic habitats (Noireau et al. 1999, 2002). If we overlay the reported locations of wild T. infestans on the biogeographic regions of Bolivia, the highland foci are clearly located in the InterAndean Dry Forest, whereas the lowland foci occur in the Gran Chaco Region. The case for a wide distribution of wild $T$. infestans within these biogeographic regions is strengthened by the increase in the number of surveys that were often successful in detecting sylvatic populations. The wild populations of the Andes and the Chaco seem to be geographically isolated; no sylvatic T. infestans foci have been found to date in the Andean foothills (the Tucuman-Bolivian Forest and Chaco Serrano biogeographic regions). Because wild T. infestans have a wide distribution throughout the Bolivian Andes and the Gran Chaco, the notion of foci should be interpreted as geographically restricted records, which probably represent point occurrence data from a more widespread population. The distribution of wild T. infestans may not be restricted to small areas, but may extend to all of the biogeographic regions mentioned above. A new idea of great consequence is the existence of sylvatic $T$. infestans in periurban environments, as demonstrated in Cochabamba. In this large Andean city $(>500,000$ inhabitants, 2001 census), soaring urbanisation in the southern zone disregards the occurrence of wild $T$. infestans that are readily captured in the immediate outskirts of new settlements.

\section{The different morphs of wild $T$. infestans and some traits of their biology and ecology}

The sylvatic ecology and the role of wild $T$. infestans in the transmission of Trypanosoma cruzi are still poorly understood despite the number and diversity of foci recorded. Wild Andean T. infestans occur chiefly in rocky outcrops, which, regardless of their size, represent suitable refuges for the species. These Andean populations of $T$. infestans display a chromatic pattern (Table) similar to that of their domestic counterparts in all of the Southern Cone countries, except for some populations named "Mataral morphs", which are found in the South-Eastern Cochabamba department $(\sim 1,800 \mathrm{~m}$ asl) and are larger, with noticeably different marks on the connexivum (Cortez et al. 2007). In the Cotapachi region of the Cochabamba Valley, we collected nymphs and adults of T. infestans in 30\% of the outcrops where Thylamys marsupials and rodent species of Bolomys, Philotys and Akodon find shelter. A yearly pattern of the populationstage structure, which is characterised by only one emergence peak of young nymphs that corresponds to the production of one generation a year, was found in Andean wild T. infestans (Cortez et al. 2007). Mammal hosts and insects both presented very high levels of $T$. cruzi infection ( $>60 \%$ ). In spite of the prevalence of both T. cruzi lineages (TCI and TCII) in the domestic cycle in the Cochabamba Valley, only TCI seems to be transmitted between wild small mammals and T. infestans (Cortez et al. 2006, 2007). Rupicolous (inhabiting rocks) T. infestans populations that were recently found in the north Potosi department (Toro Toro area) are interesting, because they live in fissures in cliffs where the red-fronted macaw (Ara rubrogenys) and other birds nest (M Baune, personal communication). In contrast, wild $T$. infestans from the Chaco $(<400 \mathrm{~m}$ asl) are arboreal (inhabiting trees). Their overall darker coloration ("dark morph") distinguishes them from the other forms of $T$. infestans, either domestic or sylvatic (Noireau et al. 1997, 2005). They are found inside the trunks of emergent trees, in hollows occupied by blue-fronted parrots (Amazona aestiva). The very low

TABLE

The different morphs and geographic populations of wild Triatoma infestans and some traits of their bioecology

\begin{tabular}{|c|c|c|c|c|}
\hline Name & Common morph & Common morph & Mataral morph & Dark morph \\
\hline $\begin{array}{l}\text { Distinguishing morphochromatic } \\
\text { traits with the common morph }\end{array}$ & - & - & $\begin{array}{l}\text { Large size }(>30 \mathrm{~mm}), \\
\text { great yellow markings } \\
\text { on the connexivum }\end{array}$ & $\begin{array}{l}\text { Overall dark coloration, } \\
\text { small yellow markings } \\
\text { on the connexivum }\end{array}$ \\
\hline Area of endemism & $\begin{array}{l}\text { Inter-Andean, } \\
\text { dry Forest } \\
(>2,000 \mathrm{~m} \text { asl })\end{array}$ & $\begin{array}{c}\text { Toro Toro area, } \\
\text { inter-Andean Dry } \\
\text { Forest }(\sim 2,000 \mathrm{~m} \text { asl })\end{array}$ & $\begin{array}{l}\text { Inter-Andean dry forest, } \\
\text { southeastern Cochabamba } \\
\text { department }(\sim 1,800 \mathrm{~m} \text { asl })\end{array}$ & $\begin{array}{l}\text { Lowlands of the } \\
\text { Gran Chaco } \\
(<400 \mathrm{~m} \text { asl })\end{array}$ \\
\hline Habitat & Rocky outcrops & Cliffs & Rocky outcrops & Hollow trees \\
\hline Preferential host-feeding & Small mammals & $\begin{array}{c}\text { Birds } \\
\text { (probably parrots) }\end{array}$ & $\begin{array}{l}\text { Probably } \\
\text { small mammals }\end{array}$ & $\begin{array}{c}\text { Birds } \\
\text { (probably parrots) }\end{array}$ \\
\hline Trypanosoma cruzi infection rates & High & Low & High & Low \\
\hline
\end{tabular}

asl: above sea level. 
T. cruzi infection rate detected in the dark morph (2.5\%) supports its ornithophilic tendency (Noireau et al. 2000, Ceballos et al. 2009). The stage-structure pattern of the dark morph population is still unknown. Although domestic $T$. infestans produce two generations a year in the warm climate of the Chaco (Gorla \& Schofield 1989), fluctuations in host availability in wild habitats might put the dark morph at a disadvantage and lead to an increased development time.

Particularly interesting is the considerable behavioural and chromatic plasticity displayed by wild $T$. infestans. According to the biogeographic region, the vectors occur in rupicolous (rock-piles or cliffs) or arboreal habitats, unlike almost all other triatomine species, which show a marked preference for a type of habitat. Similarly, we observed obvious chromatic differences between rupicolous specimens (common form and Mataral morph) and between the Andean and arboreal $T$. infestans from the lowlands (dark morph populations but also Triatoma melanosoma) (Martinez et al. 1987).

\section{The origin of $T$. infestans as a species}

Since wild populations were initially found in the Bolivian highlands, Andean T. infestans are generally assumed to represent the most ancient form (Usinger et al. 1966, Schofield 1988). The detection of wild T. infestans in the Boreal Chaco in the late 1990s challenged the traditional view that the Andean valleys in Bolivia were the only centre of origin and dispersal of $T$. infestans throughout South America. The most ancient populations may be those of the dry, subtropical Chaco forest in South-Eastern Bolivia, Paraguay and Northern Argentina (Carcavallo et al. 2000). This Chacoan proposal is also based on the broader biogeographical patterns of the species group to which infestans belongs. However, recent findings based on allozymes, genome size and nuclear rDNA favour the Andean hypothesis (Dujardin et al. 1998, Panzera et al. 2004, Bargues et al. 2006). This would imply that the dark morph populations, which exhibit an important reduction of heterochromatin and DNA amounts as well as a considerable degree of genetic isolation, represent a direct expansion from the Andean populations (Monteiro et al. 1999, Giordano et al. 2005, Piccinali et al. 2009). However, the occurrence of at least one recolonisation of a sylvatic habitat from a domestic population in the Chaco was not discarded (Panzera et al. 2004, Bargues et al. 2006). The detection of the Mataral morph of T. infestans in the inter-Andean Chaco (i.e., intermediate between the high Andean valleys and the Chaco) further complicates the question.

\section{The origin of $T$. Infestans domestic populations}

The introduction of $T$. infestans into domestic environments would have been a consequence of a vector transition from rodent burrows to the cave-like habitations of pre-Columbian peoples, where the microclimatic conditions were not too dissimilar (Usinger el al. 1966). Later, Schofield (1988) put forward the traditional speculation of $T$. infestans adaptation to the synanthropic environment as a consequence of the domestication of wild guinea pigs, one of its natural hosts, by Andean tribes in approximately 5,000 BC. After this first step of adaptation to the domestic environment, $T$. infestans would then have dispersed throughout other countries of South America, apparently in association with human migrations, ultimately reaching Brazil during the 20th century (Schofield 1988). A further speculation, based this time on the passive dispersal of sylvatic $T$. infestans, has been recently put forward. It involves organised human social activities, in particular maize production and storage in the Cochabamba valley (MR Cortez et al., unpublished observations). The spread of the vector would have been a consequence of the transport and distribution of maize hosting the associated fauna (wild rodent populations and insects) throughout distant provinces of the Inca Empire.

\section{Microgeographic genetic diversity of wild $T$. infestans}

Until recently, T. infestans populations were believed to have low levels of genetic variability (Schofield 1988, Guhl \& Schofield 1996). Most studies were based on allozymes and reported low polymorphism as inferred from results on two or three polymorphic loci (Pereira et al. 1996, Dujardin et al. 1998). Recent studies based on mitochondrial or nuclear gene sequences from domestic populations detected higher levels of genetic variation than expected (Giordano et al. 2005, Bargues et al. 2006, Piccinali et al. 2009). To assess the genetic variability in a wild $T$. infestans population, a mitochondrial cytochrome b (Cytb) gene fragment was sequenced in insects sampled from a very small area $\left(<1 \mathrm{~km}^{2}\right)$ in the Cochabamba valley, at $2,700 \mathrm{~m}$ asl. The results showed high genetic variability: seven haplotypes were identified in 38 triatomines analysed (P Kengne \& F Noireau, unpublished observations). Among the sylvatic haplotypes, two of them were also found in domestic insects from the Sucre Region (Giordano et al. 2005). The detection of seven haplotypes in wild $T$. infestans from a limited area supports the evolutionary theory, which predicts higher genetic variability in the ancestral wild populations than in their domestic derivatives (Dujardin et al. 1999).

\section{Dispersal ability of wild $T$. infestans at high altitude}

The key question regarding the threat represented by wild populations of T. infestans is whether they can recolonise insecticide-treated villages and thus jeopardise control efforts. Therefore, it is essential to assess the dispersal of wild $T$. infestans and the extent of gene flow between sylvatic and domestic populations. In a dispersal study performed in the Cochabamba valley at $2,700 \mathrm{~m}$ asl, the detection of restricted gene flow between close, but distinct, sylvatic sites (rocky outcrops) was consistent with the hypothesis that the vectors do not disperse by flying at high altitude (Richer et al. 2007). Some studies on the ability of $T$. infestans to fly under more favourable conditions (in the lowlands of the Chaco) pointed out that this species showed flight potential on a village-wide scale and in sylvatic environments (Schofield et al. 1992, Noireau et al. 2000, Vazquez-Prokopec et al. 2006). However, the results of Richer et al. (2007) suggested that, at 2,700 $\mathrm{m}$ asl in the Andes, wild T. infestans gradually disperse over a small distance by walk- 
ing within a "patch", which might be characterised as a continuous land cover with all necessary resources for the persistence of triatomine populations (Gustafson \& Gardner 1996). On the other hand, when the land cover is disrupted by human activities (e.g., building of dwellings and peridomestic structures, land or livestock farming), triatomine bugs encounter an unsuitable environment and cannot spread to separate patches by walking. However, the results of this highlands study probably cannot be extended to regions with different environmental conditions. Consequently, it is essential to determine the role that wild T. infestans populations may play as potential sources of reinfestation in the different ecoregions where they are found.

\section{Current arguments regarding the epidemiological significance of the wild $T$. infestans}

The following question deserves to be asked: does a relationship exist between the persistent vector infestation in certain areas and the occurrence of wild $T$. infestans? In other terms, do wild T. infestans threaten to recolonise insecticide-treated areas? There are increasing reports of wild triatomine species invading human dwellings in areas where domestic vector populations have been targeted by chemical control interventions. In certain cases, the initial phenomenon of the intrusion of adult bugs into households may continue until the establishment of domestic breeding colonies (Noireau et al. 1994, 1995). Why would wild T. infestans be excluded from such a process even though this species has successfully adapted to domestic environments in the past? Several observations support the epidemiological risk represented by wild T. infestans: (i) Currently, domestic T. infestans still persists in only the Andean valleys of Bolivia and in the Gran Chaco Region; interestingly, wild populations of $T$. infestans are widespread throughout these precise regions; (ii) Another argument is based on mitochondrial genetic variability (COI and Cytb genes). Various haplotypes are shared by both domestic and sylvatic Andean populations (Monteiro et al. 1999, Piccinali et al. 2009). Moreover, and as previously mentioned, two Cytb haplotypes isolated from wild triatomines in Cochabamba are also shared by domestic insects from Cochabamba and Sucre; (iii) The Mataral form, found in sylvatic environments in the south-eastern Cochabamba department, is also colonising houses of the same region ( $F$ Noireau, unpublished observations); (iv) T. infestans was, without any doubt, the triatomine species that displayed the most successfully completed process of domestication. It began this process in Bolivia, probably in the Andean mesothermic valleys, before spreading by passive transportation associated with human activities (Schofield 1988, Bargues et al. 2006). It is difficult to give credit to the hypothesis that sylvatic forms of T. infestans would have become restricted to their natural habitat since then, whereas many other sylvatic species are currently involved in a process of domestic intrusion.

However, current evidence does not support a continued flow of $T$. infestans between sylvatic refuges and domestic environments. In the Andes, climatic factors may hamper the process of domestic intrusion by wild $T$. infestans. Between 1,700-2,800 $\mathrm{m}$ asl, the altitude range where $T$. infestans wild populations are widespread, the crepuscular coldness restricts flight dispersal. In the Chaco, certain environmental characteristics might hamper the process of domestic intrusion by the dark morph. Emergent trees, which offer stable refuges for the vectors that live in parrot nests located within trunks, have become scarce in the vicinity of the villages and only persist in areas free of environmental damage caused by humans. Moreover, intensive hunting of parrots would also lead to the destruction of nests and the extinction of triatomine colonies. Consequently, the T. infestans dark morph would persist in preserved and remote wooded areas and would be scarce near human settlements.

As a whole, these observations suggest that the climatic and environmental conditions of their distribution areas would not favour a continued flow of triatomines between sylvatic and domestic environments, even if wild $T$. infestans retained its potential to invade and colonise human dwellings. Contrary to Rhodnius prolixus, for which a continued flow between palm trees and houses has been revealed (Fitzpatrick et al. 2008), only unusual circumstances would generate a continued transfer of $T$. infestans from the natural to the domestic environment. The direct consequence will be the need to use suitable hypervariable genetic markers to detect this restricted gene flow.

\section{REFERENCES}

Bacigalupo BA, Segura MJA, Garcia CA, Hidalgo CJ, Galuppo GS, Cattan PE 2006. Primer hallazgo de vectores de la enfermedad de Chagas asociados a matorrales silvestres en la Región Metropolitana, Chile. Rev Méd Chile 134: 1230-1236.

Bargues MD, Klisiowicz DR, Panzera F, Noireau F, Marcilla A, Perez R, Cortez MR, O’Connor JE, Gonzáles-Candelas F, Galvão C, Jurberg J, Carcavallo RU, Dujardin JP, Mas-Coma S 2006. Origin and phylogeography of the Chagas disease main vector Triatoma infestans based on nuclear rDNA sequences and genome size. Infect Genet Evol 6: 46-62.

Barretto MP, Siqueira AF, Corrêa FMA 1963. Estudos sôbre reservatórios e vetores silvestres do Trypanosoma cruzi. I. Encontro do Triatoma infestans em ecótopos silvestres. Rev Inst Med Trop Sao Paulo 5: 289-293.

Bejarano JFR 1967. Estado selvático de T. infestans y otros aspectos a tener en cuenta para la eliminación de la enfermedad de Chagas. 2da Jorn Entomoepidemiol Arg 3, p. 171-196.

Bermudez H, Balderrama F, Torrico F 1993. Identification and characterization of sylvatic foci of Triatoma infestans in Central Bolivia. Am J Trop Med Hyg 49 (Suppl.): 371.

Carcavallo RU, Jurberg J, Lent H, Noireau F, Galvão C 2000. Phylogeny of the Triatominae (Hemiptera: Reduviidae). Proposals for taxonomic arrangements. Entomol Vect 7: 1-99.

Ceballos LA, Piccinali RV, Berkunsky I, Kitron U, Gürtler RE 2009. First finding of melanic sylvatic Triatoma infestans (Hemiptera: Reduviidae) colonies in the Argentine Chaco. J Med Entomol 46, in press.

Cichero JA, Gimenez AL, Martinez A 1984. Estudio de los vectores de la enfermedad de Chagas en ambientes silvestres, peridomésticos y domésticos. Chagas 1: 33-37. 
Cortez MR, Emperaire L, Piccinali RV, Gürtler RE, Torrico F, Jansen AM, Noireau F 2007. Sylvatic Triatoma infestans (Reduviidae, Triatominae) in the Andean valleys of Bolivia. Acta Trop 102: 47-54.

Cortez MR, Pinho AP, Cuervo P, Alfaro F, Solano M, Xavier SCC, D'Andrea PS, Fernandes O, Torrico F, Noireau F, Jansen AM 2006. Trypanosoma cruzi (Kinetoplastida: Trypanosomatidae): ecology of the transmission cycle in the wild environment of the Andean valley of Cochabamba, Bolivia. Exp Parasitol 114: 305-313.

Dias JCP 2007. Southern Cone Initiative for the elimination of domestic populations of Triatoma infestans and the interruption of transfusional Chagas disease. Historical aspects, present situation and perspectives. Mem Inst Oswaldo Cruz 102 (Suppl. I): 11-18.

Dujardin JP, Panzera P, Schofield CJ 1999. Triatominae as a model of morphological plasticity under ecological pressure. Mem Inst Oswaldo Cruz 94 (Suppl. I): 223-228.

Dujardin JP, Schofield CJ, Tibayrenc M 1998. Population structure of Andean Triatoma infestans: allozyme frequencies and their epidemiological relevance. Med Vet Entomol 12: 20-29.

Dujardin JP, Tibayrenc M, Venegas E, Maldonado P, Desjeux P, Ayala FJ 1987. Isozyme evidence of lack of speciation between wild and domestic Triatoma infestans (Heteroptera: Reduviidae) in Bolivia. J Med Entomol 24: 40-45.

Fitzpatrick S, Feliciangeli MD, Sanchez-Martin MJ, Monteiro FA, Miles MA 2008. Molecular genetics reveal that silvatic Rhodnius prolixus do colonise rural houses. PLoS Negl Trop Dis 2: e210.

Giordano R, Pizarro Cortez JC, Paulk S, Stevens L 2005. Genetic diversity of Triatoma infestans (Hemipetra: Reduviidae) in Chuquisaca, Bolivia, based on the mitochondrial cytochrome $\mathrm{b}$ gene. Mem Inst Oswaldo Cruz 100: 753-760.

Gorla DE 2002. Variables ambientales registradas por sensores remotos como indicadores de la distribución geográfica de Triatoma infestans (Heteroptera: Reduviidae). Ecol Austral 12: 117-127.

Gorla DE, Schofield CJ 1989. Population dynamics of Triatoma infestans under natural climatic conditions in the Argentine Chaco. Med Vet Entomol 3: 179-194.

Guhl F, Schofield CJ 1996. Population genetics and control of Triatominae. Parasitol Today 3: 169-170.

Gustafson EJ, Gardner RH 1996. The effect of landscape heterogeneity on the probability of patch colonization. Ecology 77: 94-107.

Martinez A, Olmedo RA, Carcavallo RU 1987. Una nueva subespecie Argentina de Triatoma infestans. Chagas 4: 7-8.

Mazza S 1943. Comprobaciones de Triatoma platensis, Eutriatoma oswaldoi, Panstrongylus seai y Psammolestes coreodes en la Provincia de Santiago del Estero, todos ellos sin infestación y de Eutriatoma sordida con infestación por S. cruzi. Otros datos sobre infestación esquizotripanósica natural silvestre de Triatoma infestans. Prensa Med Arg 30: 1-23.

Monteiro FA, Perez R, Panzera F, Dujardin JP, Galvão C, Rocha D, Noireau F, Schofield C, Beard CB 1999. Mitochondrial DNA variation of Triatoma infestans populations and its implication on the specific status of T. melanosoma. Mem Inst Oswaldo Cruz 94 (Suppl. I): 229-238.

Noireau F, Abad-Franch F, Valente SAS, Dias-Lima A, Lopes CM, Cunha V, Valente VC, Palomeque FS, Carvalho-Pinto CJ, Sherlock I, Aguilar M, Steindel M, Grisard EC, Jurberg J 2002. Trapping Triatominae in silvatic habitats. Mem Inst Oswaldo Cruz 97: 61-63.

Noireau F, Bosseno MF, Carrasco R, Telleria J, Vargas F, Camacho C, Yaksic N, Brenière F 1995. Sylvatic triatomines (Hemiptera:
Reduviidae) in Bolivia. Trends towards domesticity and possible infection with Trypanosoma cruzi (Kinetoplastida: Trypanosomatidae). J Med Entomol 32: 594-598.

Noireau F, Cortez MR, Monteiro FA, Jansen AM, Torrico F 2005. Can wild Triatoma infestans foci in Bolívia jeopardize Chagas disease control efforts? Trends Parasitol 21: 7-10.

Noireau F, Flores R, Gutierrez T, Abad-Franch F, Flores E, Vargas F 2000. Natural ecotopes of Triatoma infestans dark morph and other wild triatomines in the Bolivian Chaco. Trans $R$ Soc Trop Med Hyg 94: 23-27.

Noireau F, Flores R, Gutierrez T, Dujardin JP 1997. Detection of wild dark morphs of Triatoma infestans in the Bolivian Chaco. Mem Inst Oswaldo Cruz 92: 583-584.

Noireau F, Flores R, Vargas F 1999. Trapping sylvatic Triatominae (Reduviidae) in hollow trees. Trans R Soc Trop Med Hyg 93: 13-14.

Noireau F, Vargas F, Bosseno MF, Brenière SF 1994. Apparent trend to domesticity observed in Panstrongylus rufotuberculatus (Hemiptera: Reduviidae) in Bolivia. Res Rev Parasitol 54: 249-250.

Panzera F, Dujardin JP, Nicolini P, Caraccio MN, Rose V, Tellez T, Bermudez H, Bargues MD, Mas-Coma S, O'Connor JE, Perez R 2004. Genomic changes of Chagas disease vector, South America. Emerg Infect Dis 10: 438-446.

Pereira J, Dujardin JP, Salvatella R, Tibayrenc M 1996. Enzymatic variability and phylogenic relatedness among Triatoma infestans, T. platensis, T. delpontei and T. rubrovaria. Heredity 77: 47-54.

Piccinali RV, Marcet PL, Noireau F, Kitron U, Gürtler RE, Dotson EM 2009. Molecular population genetics and phylogeography of the Chagas disease vector Triatoma infestans in South America. $J$ Med Entomol, in press.

Richer W, Kengne P, Cortez MR, Perrineau MM, Cohuet A, Fontenille D, Noireau F 2007. Active dispersal by wild Triatoma infestans in the Bolivian Andes. Trop Med Int Health 12: 759-764.

Schmunis GA, Zicker F, Moncayo A 1996. Interruption of Chagas disease transmission through vector elimination. Lancet 348: 1171.

Schofield CJ 1988. Biosystematics of the Triatominae. In M Service (ed.), Biosystematics of Haematophagous Insects, Clarendon Press, Oxford, p. 284-312.

Schofield CJ, Jannin J, Salvatella R 2006. The future of Chagas disease control. Trends Parasitol 22: 583-588.

Schofield CJ, Lehane MJ, McEwan P, Catalá SS, Gorla DE 1992. Dispersive flight by Triatoma infestans under natural climatic conditions in Argentina. Med Vet Entomol 6: 313-317.

Torrico RA 1946. Hallazgo de Eratyrus mucronatus, infestación natural de "vinchucas" de cerro y Eutriatoma sordida en Cochabamba. An Lab Central Cochabamba 1: 19-23.

Usinger RL, Wygodzinsky P, Ryckman RE 1966. The biosystematics of Triatominae. Annu Rev Entomol 11: 309-330.

Vazquez-Prokopec GM, Ceballos LA, Marcet PL, Cecere MC, Cardinal MV, Kitron U, Gürtler RE 2006. Seasonal variations in active dispersal of natural populations of Triatoma infestans in rural north-western Argentina. Med Vet Entomol 20: 273-279.

Velasquez CJ, González G 1959. Aspectos de la enfermedad de Chagas en Paraguay. Rev Goiana Med 5: 357-373.

Yeo M, Acosta N, Llewellyn M, Sánchez H, Adamson S, Miles GAJ, López E, González N, Patterson JS, Gaunt MW, Arias AR, Miles MA 2005. Origins of Chagas disease: Didelphis species are natural hosts of Trypanosoma cruzi I and armadillos hosts of Trypanosoma cruzi II, including hybrids. Int J Parasitol 35: 225-233. 